\title{
O uso do espaço urbano sob a ótica publicitária em tempos de convergência
}

\author{
The use of urban space in the advertising perspective on convergence
}

times

http://dx.doi.org/10.5007/2178-4582.2015v49n2p20

Enrico Rosa Trevisan

Centro Universitário Senac, São Paulo/SP, Brasil

\begin{abstract}
Este artigo discute o espaço ocupado pela mídia e a relação que o homem estabelece com os meios de comunicação na sociedade contemporânea. A partir de uma retrospectiva teórica sobre a evolução dos meios de comunicação, articula três abordagens conceituais acerca da mídia, com base nas ideias de Marshall McLuhan, Douglas Kellner e Henry Jenkins. Discute o impacto das transformações tecnológicas no campo da comunicação no contexto de uma cultura de convergência, com base em algumas campanhas publicitárias recentes. Aponta a tendência atual de uso do espaço urbano como temática de campanhas publicitárias em consequência de um certo desgaste do ambiente midiático na percepção do consumidor e apresenta esta temática como uma alternativa de discurso publicitário, sob a ótica de planejamento de comunicação.

Palavras-chave: mídia - cultura de convergência - comportamento do consumidor - campanhas publicitárias - espaço urbano.
\end{abstract}

This article aims to discuss the place occupied by media and the relationship man establishes with means of communication in contemporary society. From a historical retrospective on the evolution of communication theory, this article articulates three theoretical approaches to media, based on Marshall McLuhan, Douglas Kellner and Henry Jenkins' ideas. It discusses the impact of technological transformations in the communications realm in a convergence culture context, based on recent advertising campaigns. It presents a current trend of urban space usage as a theme of advertising campaigns in response to a certain overuse and consequent aversion of the media spectrum perceived by users and consumers while presenting this subject as an alternative to advertising discourse, from a marketing plan point of view

Keywords: media - convergence culture-consumer behaviour - advertising campaigns - urban space.

\section{Introdução}

A edição de fim de semana do jornal americano The Wall Street Journal, de 3 e 4 de janeiro de 2015, deu destaque à apresentação do novo livro de David Kynaston (2014), intitulado Modernity Britain: Opening the Box, 19571959 (ou Bretanha na Modernidade: Abrindo a Caixa, 1957-1959). A foto que ilustra a capa do livro de Kynaston mostra uma família comum: um pai, uma mãe e o casal de filhos reunidos em frente a um aparelho de televisão. A fotografia em preto e branco é só mais um dos elementos que compõem o retrato de uma época: o corte de cabelo dos pais, o cigarro na mãos da mãe, as calças ainda curtas do menino sentado no chão e a moldura de madeira que envolve a TV. Uma contextualização histórica cheia de detalhes. 
O texto de Martin Rubin (2015), intitulado Before the Beatle's First LP (Antes do Primeiro LP dos Beatles) apresenta o terceiro volume da obra do historiador Kynaston que, em seu conjunto, contempla o período entre o fim da 2a Guerra Mundial até 1979, ano em que Margareth Thatcher se torna Primeira Ministra do Reino Unido. A reportagem faz uma descrição bastante detalhada sobre o período em que eletrodomésticos - como a televisão e máquinas de lavar roupa - adentraram as residências das donas de casa na Grã-Bretanha. O próprio autor o descreve como "um período de mudanças significativas que, curiosamente, não apresenta um evento definidor" (KYNASTON, 2015) como os demais títulos da trilogia que partem ou terminam em um evento histórico específico. O livro aborda a importância de uma época em que mudanças tecnológicas se tornaram marcos importantes para a construção de diversas análises sobre o espaço ocupado pela mídia em nossas vidas cotidianas e na relação que estabelecemos com os meios de comunicação.

A referência à obra de Kynaston na abertura deste artigo se justifica pela coincidência cronológica com as teorias de Marshall McLuhan, de meados dos anos 1960, sobre os impactos sociais daquilo que a matéria do The Wall Street Journal denominou como "a caixa que conquistou a Bretanha": a televisão (RUBIN, 2015). O presente estudo tem como objetivo refletir sobre os desdobramentos teóricos desse tema que culmina com a tendência atual de uso do espaço urbano como temática de campanhas publicitárias em consequência de um certo desgaste do ambiente midiático na percepção do consumidor.

Para tanto, realiza-se uma breve retrospectiva histórica das teorias que abordam a mídia e os meios de comunicação com o intuito de demarcar a evolução de algumas análises conceituais acerca do comportamento social e seu impacto em outro fenômeno social: a propaganda. Em seguida, propõe-se uma reflexão sobre os efeitos de um contexto de excesso de informações - sejam elas comerciais ou não - que levam os indivíduos a manifestarem anseios por um êxodo deste cenário. Diante disso, procura-se contextualizar e sugerir as consequências dessa aceleração do fluxo de conteúdo de mídia no âmbito comunicacional e demonstrar a tendência das campanhas publicitárias a adotarem uma nova postura de aproximação com o seu público-alvo, exatamente por acreditarem que as barreiras e defesas estabelecidas pelos consumidores em relação aos anunciantes e produtores de conteúdo midiático podem ser diminuídas se forem evocados novos espaços de comunicação.

\section{A evolução dos meios de comunicação e as teorias acerca de mídia.}

O período entre o final dos anos 1950 até meados dos anos 1960 constitui o contexto histórico de uma das notáveis análises sobre mídia e a relação do 
homem com os meios de comunicação. Marshall McLuhan, em Os Meios de Comunicação como Extensões do Homem (2003), inicia sua obra com a afirmação contundente de que "o meio é a mensagem". Em sua análise sobre o papel que os meios de comunicação desempenham na sociedade, o autor apresenta as características definidoras de meio, como veículo, e da mensagem como conteúdo, colocando em questão os fundamentos essenciais desses dois termos. McLuhan afirma, por exemplo, que a luz elétrica só é percebida como meio quando lhe é atribuído um "conteúdo".

Pouca diferença faz que seja usada para uma intervenção cirúrgica no cérebro ou para uma partida noturna de beisebol. Poderia objetar-se que essas atividades, de certa maneira, constituem o "conteúdo" da luz elétrica, uma vez que não poderiam existir sem ela. Este fato apenas serve para destacar que o ponto de que o meio é a mensagem, porque é o meio que configura e controla a proporção e a forma das ações e associações humanas (McLUHAN, 2003, p.22).

\section{O autor ainda explica que:}

Não percebemos a luz elétrica como meio de comunicação simplesmente porque ela não possui "conteúdo". É o quanto basta para exemplificar como se falha no estudo dos meios e veículos. Somente compreendemos que a luz elétrica é um meio de comunicação quando utilizada no registro do nome de algum produto. (Ibid., p. 23)

O que McLuhan faz, a partir desta análise sobre a essência dos meios de comunicação, é definir tipos de meios pelo ponto de vista de interação e participação pelo receptor ou espectador. Ele estabelece, então, a distinção entre meios quentes e meios frios.

Há um princípio básico pelo qual se pode distinguir um meio quente, como o rádio, de um meio frio como o telefone, ou de um meio quente, como o cinema, de um meio frio, como a televisão. Um meio quente é aquele que prolonga um único dos nossos sentidos e em 'alta definição'. Alta definição se refere a um estado de alta saturação de dados. Visualmente, uma fotografia se distingue pela 'alta definição' Já uma caricatura ou um desenho animado são de 'baixa definição', pois fornecem pouca informação visual. O telefone é um meio frio, ou de baixa definição, porque ao ouvido é fornecida uma magra quantidade de informação. A fala é um meio frio de baixa definição, porque muita coisa deve ser preenchida pelo ouvinte. De outro lado, os meios quentes não deixam muita coisa a ser preenchida ou completada pela audiência. Segue-se naturalmente que um meio quente, como o rádio, 
e um meio frio, como o telefone, têm efeitos bem diferentes sobre seus usuários. (McLUHAN, 2003, p.38)

Em suma, ao caracterizar os tipos de meios, McLuhan fundamenta suas posições sobre como os meios de comunicação poderiam ser estudados e, por sua vez, utilizados como ferramentas de disseminação de posições políticas e ideológicas tendo o controle social como principal foco de atenção.

Em direção contrária à teoria de McLuhan sobre o uso da mídia, seja ela quente ou fria, como forma de controle social ou de doutrinação ideológica, Douglas Kellner aponta, em A Cultura da Mídia (2001), que há espaço para questionamento pelo público receptor da cultura de mídia. Kellner defende que, embora a indústria criativa utilize técnicas avançadas de persuasão, as pessoas "podem resistir aos significados e mensagens dominantes, criar sua própria leitura e seu próprio modo de apropriar-se da cultura de massa, usando a sua cultura como recurso para fortalecer-se, inventar significados, identidade e forma de vida próprios." (KELLNER, 2001, p.11)

Embora acredite que o receptor tenha livre escolha para assimilar ou descartar as posições veiculadas em componentes midiáticos, em sua análise sobre as teorias que circundam o tema mídia e a relação do homem com os meios de comunicação, Kellner reconhece a destreza com que são apresentadas:

\begin{abstract}
Em geral, não é um sistema de doutrinação ideológica rígida que induz à concordância com as sociedades capitalistas existentes, mas sim os prazeres pela mídia e pelo consumo. O entretenimento oferecido por esses meios frequentemente é agradabilíssimo e utiliza instrumentos visuais e auditivos, usando o espetáculo para seduzir o público e levá-lo a identificar-se com certas opiniões, atitudes, sentimentos e disposições (KELLNER, 2001, p. 11).
\end{abstract}

Ao esclarecer sua posição sobre a construção de componentes culturais a partir dos meios de comunicação, Kellner também analisa historicamente as teorias sobre o aumento do número de veículos apresentados ao homem em seu cotidiano. Contextualiza o leitor sobre as diversas posições teóricas que circundam seu tema de estudo: a cultura de mídia.

Já nos anos 1950, os teóricos sociais proclamavam o advento de novas sociedades pós-industriais nas quais os conhecimento e a informação seriam o 'princípio axial' em torno do qual a sociedade se organizaria (Bell 1960, 1973 e 1976). Durante os anos 1970, começaram a surgir argumentos de que a modernidade estava acabada, e de que estávamos agora numa nova era pós-moderna (Baudrillard, 1976 e Lyotard 1984) - argumentos 
que geraram uma explosão de discursos sobre o pós-modernismo nos anos 1970 e 1980 (Best e Kellner 1991). (KELLNER, 2001, p. 27-28).

Passando pelos anos 1950, 1960 e 1970, o autor deixa evidente a dissonância entre teóricos sobre o que acontecera, o que estava acontecendo e o que viria a acontecer nesta temática, destacando posições e pontos de vista divergentes sobre o mesmo assunto.

\begin{abstract}
Alguns teóricos do pós-modernismo argumentam que as sociedades contemporâneas, com suas novas tecnologias, novas formas de cultura e novas experiências do presente, constituem uma ruptura decisiva em relação às formas modernas de vida. Para eles, o cativo ao sofá, incansável surfista das ondas de TV, e o jóquei do computador plugado no ciberespaço e nos novos mundos da informação e do entretenimento constituem um espantoso desenvolvimento evolucionário, uma decisiva novidade na aventura humana. Os midiólatras e tecnomaníacos da atualidade são vistos como caçadores-coletores de informações e entretenimento, desafiados a sobreviver a uma sobrecarga de 'infoentretenimento' e a processar uma espantosa quantidade de imagens e ideias (Ibid., p. 28).
\end{abstract}

Em contraposição a esta análise pós-modernista dos avanços tecnológicos em relação aos meios de comunicação, Kellner faz menção a leituras realizadas na década de 1980, de ordem econômica, e mais relacionadas à produção em massa e ao consumo.

Ao mesmo tempo, os economistas políticos começam a dizer que estamos entrando numa nova sociedade 'pós-fordista' em que o regime de acumulação caracterizado pela produção e pelo consumo de massa, pela regulação estatal da economia e por um cultura de massa homogênea está sendo substituído por regimes 'mais flexíveis' de acumulação (Harvey 1989). Estes são caracterizados por empresas transnacionais, que substituem o Estado-nação como árbitro da produção numa nova era de produção global que apaga as fronteiras anteriores de espaço e tempo. Outros teóricos sociais falam em 'capitalismo desorganizado’ ou em novas formas de organização, bem como em novas crises de legitimação, novos riscos, problemas ecológicos, desagregação da comunidade, abismos cada vez maiores entre ricos e pobres, novas doenças mortais como a AIDS e uma miríade de outros novos fenômenos e problemas (KELLNER, 2001, p.28).

Seja por uma mudança tecnológica que participa ativamente de nossa vida diária, ou por uma redefinição da ordem mundial de produção e de acumula- 
ção de capital, chegamos aos anos 2000 com este cenário de cultura de mídia que Kellner aponta como pano de fundo onipresente de informações que moldam pensamentos e estabelecem modelos a serem seguidos.

Há uma cultura veiculada pela mídia, cujas imagens, sons e espetáculos ajudam a urdir o tecido da vida cotidiana, dominando o tempo de lazer, modelando opiniões políticas e comportamentos sociais, e fornecendo o material com que as pessoas forjam suas identidades. O rádio, a televisão, o cinema e outros produtos da indústria cultural fornecem os modelos daquilo que significa ser homem ou mulher, bem-sucedido ou fracassado, poderoso ou impotente (Ibid., p. 9).

O que o autor designa como cultura de mídia não somente coloca em perspectiva o meio pelo qual a cultura é disseminada mas, talvez, com maior importância, propõe a discussão sobre como esta cultura, por meio de afirmações bastante divergentes de bem e mal, constrói parâmetros de julgamento e posicionamento social.

As narrativas e as imagens veiculadas pela mídia fornecem os símbolos, os mitos e os recursos que ajudam a constituir uma cultura comum para a maioria dos indivíduos em muitas regiões do mundo de hoje. A cultura veiculada pela mídia fornece o material que cria as identidades pelas quais os indivíduos se inserem nas sociedades tecnocapitalistas contemporâneas, produzindo uma nova forma de cultura global (KELLNER, 2001, p. 9).

Nessa nova forma de cultura global, o autor discute a presença constante dos veículos de comunicação no dia a dia e coloca em questão a função participativa do homem nesta equação.

A cultura, em seu sentido mais amplo, é uma forma de atividade que implica alto grau de participação, na qual as pessoas criam sociedades e identidades. [...] As pessoas passam um tempo enorme ouvindo rádio, assistindo à televisão, frequentando cinemas, convivendo com músicas, fazendo compras, lendo revistas e jornais, participando dessas e de outras formas de cultura veiculada por meios de comunicação. Portanto, trata-se de uma cultura que passou a dominar a vida cotidiana, servindo de pano de fundo onipresente e muitas vezes de sedutor primeiro plano para o qual convergem nossa atenção e nossas atividades (Ibid., p.11).

O que essas proposições não contemplam, mesmo tendo sido publicadas em 2001, são as mudanças produzidas pela popularização do uso da internet 
em quase todas as camadas sociais. Enquanto Kellner menciona o "ciberespaço", outro teórico de mídias, Henry Jenkins, usa a internet como ponto de partida de seus argumentos apresentados no livro Cultura de Convergência (2009). Este ponto de partida é apresentado ao leitor logo na introdução da obra ao relatar um fato, no mínimo peculiar, de que fotos do personagem Beto, de Vila Sésamo (anos 1970), foram veiculadas e vinculadas a facções terroristas após os ataques de 11 de setembro nos Estados Unidos.

\begin{abstract}
A história circulou no outono de 2001: Dino Ignacio, estudante secundarista filipino-americano, criou no Photoshop uma colagem de Beto, de Vila Sésamo (1970), interagindo com o líder terrorista Osama Bin Laden, como parte de uma série de imagens denominada 'Beto é do Mal' que ele postou em sua página na Internet. Outras imagens mostravam Beto como membro da Ku Klux Klan, ao lado de Hitler, vestido como o Unabomber. Era tudo brincadeira. Logo após o 11 de setembro, um editor de Bangladesh procurou na Internet imagens de Bin Laden para imprimir cartazes, camisetas e pôsteres antiamericanos. Vila Sésamo é exibida num formato adaptado; o mundo árabe, portanto, não conhecia Beto e Ênio. A imagem acabou em uma colagem de fotografias similares que foi impressa em milhares de pôsteres e distribuída em todo Oriente Médio. Repórteres da CNN registraram a improvável cena de uma multidão enfurecida marchando em passeata pelas ruas, gritando slogans antiamericanos e agitando cartazes com Beto e Bin Laden (JENKINS, 2009, p. 28).
\end{abstract}

O que Jenkins traz de novo à discussão sobre os meios de comunicação, e a relação que o homem estabelece com eles, é que há, agora, neste momento histórico de análise, a possibilidade de geração de conteúdos por parte de todos os participantes do processo de comunicação. Dessa forma, o autor apresenta uma inversão dos modelos tradicionais de teoria de comunicação, realocando os papeis de emissor e de receptor de mensagens.

Bem-vindo à cultura de convergência, onde as velhas e as novas mídias colidem, onde a mídia corporativa e a mídia alternativa se cruzam, onde o poder do produtor de mídia e o poder do consumidor interagem de maneiras imprevisíveis (Ibid., p. 29).

Esse emaranhado não-linear de construção de conhecimentos, via meios de comunicação, é o pano de fundo no qual Jenkins apresenta o conceito de convergência:

Por convergência, refiro-me ao fluxo de conteúdos através de múltiplas plataformas de mídia, à cooperação entre múltiplos mercados midiáticos e ao comportamento migratório dos públi- 
cos dos meios de comunicação, que vão a quase qualquer parte em busca de experiências de entretenimento que desejam. Convergência é uma palavra que consegue definir transformações tecnológicas, mercadológicas, culturais e sociais dependendo de quem está falando e do que imaginam estar falando (Ibid., p. 29)

Na visão de Jenkins, não existe uma seleção ou pauta sobre o que deve ser veiculado e o que não deve. Estamos falando de um ambiente comunicacional muito mais livre e democrático do que McLuhan avaliava, nos anos 1960, ser a nova ordem dos meios de comunicação. "No mundo das convergências de mídias, toda história importante é contada, toda marca é vendida e todo consumidor é cortejado por múltiplas plataformas de mídia”, afirma Jenkins (2009, p. 29).

Nesse novo momento de relação com os meios de comunicação, o autor apresenta os sistemas de mídia como sendo intrinsicamente dependentes da participação colaborativa dos seus agentes, e faz uma distinção clara sobre o que esta transformação dos meios de comunicação representa.

A circulação de conteúdos - por meio de diferentes sistemas de
mídia, sistemas administrativos de mídias concorrentes e fron-
teiras nacionais - depende fortemente da participação ativa dos
consumidores. Meu argumento aqui será contra a ideia de que
a convergência deve ser compreendida principalmente como
um processo tecnológico que une múltiplas funções dentro dos
mesmos aparelhos. Em vez disso, a convergência representa
uma transformação cultural, à medida que consumidores são
incentivados a procurar novas informações e fazer conexões em
meio a conteúdos de mídia dispersos (JENKINS, 2009, p.29).

Outro possível ponto de associação com a teoria de McLuhan é a questão da participação do receptor da mensagem. Jenkins propõe que é somente pela participação constante de todos os envolvidos no processo de comunicação que se torna possível a convergência e sua estrutura de geração de conteúdos e conhecimentos.

A expressão cultura participativa contrasta com noções mais antigas sobre a passividade dos espectadores dos meios de comunicação. Em vez de falar sobre produtores e consumidores de mídia como ocupantes de papéis separados, podemos agora considerá-los como participantes interagindo de acordo com um novo conjunto de regras, que nenhum de nós entende por completo (Ibid., p. 30).

É importante mencionar que, ao tratar da convergência como uma transformação cultural participativa, este autor propõe uma nova abordagem das 
teorias de mídia e sobre as relações que os homens estabelecem com os meios de comunicação. Diferentemente de McLuhan ou Kellner, que sustentam suas teorias na entrada da televisão nas salas de jantar das casas norte-americanas e europeias nos anos 1960, e na consolidação da presença destes meios de comunicação e de seus conteúdos audiovisuais nas décadas seguintes, Jenkins não se refere à tecnologia como fator isolado de transformação. Para ele,

A convergência não ocorre por meio de aparelhos, por mais sofisticados que venham a ser. A convergência ocorre dentro dos cérebros de consumidores individuais e em suas interações sociais com os outros. Cada um de nós constrói a própria mitologia pessoal, a partir de pedaços e fragmentos de informações extraídos do fluxo midiático e transformados em recursos através dos quais compreendemos nossa vida cotidiana. Por haver mais informações sobre determinado assunto do que alguém possa guardar na cabeça, há um incentivo extra para que conversemos entre nós sobre a mídia que consumimos (JENKINS, 2009, p. 30).

Observa-se, assim, que Jenkins coloca a tecnologia somente como uma ligação, uma ferramenta de encontro. A convergência de mídias, e seu resultante de geração participativa de conteúdo não-linear, é o principal ponto de sua atenção. Para ele, a inteligência coletiva é vista como uma fonte alternativa do poder midiático, e consiste em uma nova aprendizagem de nossas interações diárias no que chama de "cultura de convergência". "Neste momento" - afirma - "estamos usando esse poder principalmente para fins recreativos, mas em breve estaremos aplicando essas habilidades a propósitos mais sérios" (Ibid., p.30).

Jenkins, assim como Kellner, aponta que vivemos em um ambiente de sobreposição, e não de substituição evolucionista de mídias.

O conteúdo de um meio pode mudar (como ocorreu quando a televisão substituiu o rádio como meio de contar histórias, deixando o rádio livre para se tornar a principal vitrine do rock and roll), seu publico pode mudar (como ocorre quando as histórias em quadrinhos saem de voga, nos anos 1950, para entrar num nicho, hoje) e seu status social pode subir ou cair (como ocorre quando o teatro se desloca de um formato popular para um formato de elite), mas uma vez que um meio se estabelece, ao satisfazer alguma demanda humana essencial, ele continua a funcionar dentro de um sistema maior de opções de comunicação. Desde que o som gravado se tornou uma possibilidade, continuamos a desenvolver novos e aprimorados meios de gravação e reprodução de som. Palavras impressas não eliminaram as palavras faladas. O cinema não eliminou o teatro. A televisão não eliminou o rádio. Cada meio antigo foi forçado a conviver 
com os meios emergentes. É por isso que a convergência parece mais plausível como uma forma de entender os últimos dez anos de transformações dos meios de comunicação do que o velho paradigma da revolução digital. Os velhos meios de comunicação não estão sendo substituídos. Mais propriamente, suas funções e status estão sendo transformados pela introdução de novas tecnologias (JENKINS, 2009, p. 41)

A sobreposição dos meios de comunicação serve, então, para a criação de um novo "cardápio" de opções disponíveis a todos neste sistema midiático. O que torna essa abordagem de análise interessante é realmente a inversão do papel do espectador comum em relação a outros momentos históricos. A cultura de convergência o coloca numa posição de participante ativo dessa nova estrutura. E, nesta condição, ele se torna agente de mudança.

\begin{abstract}
A convergência exige que as empresas de mídia repensem antigas suposições sobre o que significa consumir mídias, suposições que moldam tanto decisões de programação quanto de marketing. Se os antigos consumidores eram tidos como passivos, os novos consumidores são ativos. Se os antigos consumidores eram previsíveis e ficavam onde mandavam que ficassem, os novos consumidores são migratórios, demonstrando uma declinante lealdade a redes ou a meios de comunicação. Se os antigos consumidores eram indivíduos isolados, os novos consumidores são mais conectados socialmente. Se o trabalho de consumidores de mídia já foi silencioso e invisível, os novos consumidores são barulhentos e públicos (Ibid., p. 46).
\end{abstract}

O consumidor não é o único que está mudando. Para Jenkins, as empresas de mídia estão batalhando para entender o seu lugar neste novo sistema midiático e estão medindo as consequências de suas decisões.

À medida que passam por essas transformações, as empresas de mídia não estão se comportando de forma monolítica; com frequência, setores diferentes da mesma empresa estão procurando estratégias radicalmente diferentes, refletindo a incerteza a respeito de como proceder. Por um lado, a convergência representa uma oportunidade de expansão aos conglomerados de mídia, já que o conteúdo bem sucedido num setor pode se espalhar por outras plataformas. Por outro lado, a convergência representa um risco, já que a maioria dessas empresas teme uma fragmentação ou uma erosão em seus mercados. Cada vez que deslocam um espectador, digamos, da televisão para a Internet, há o risco de ele não voltar mais (Ibid., p. 47).

Este cenário é apresentado, por este autor, como inevitável e já estabelecido, trazendo à atualidade a linha histórica de teorias de mídia. 
A convergência das mídias é mais do que apenas uma mudança tecnológica. A convergência altera a lógica pela qual a indústria midiática opera e pela qual os consumidores processam a notícia e o entretenimento. Lembrem-se disto: a convergência refere-se a um processo, não a um ponto final. Não haverá uma caixa preta que controlará o fluxo midiático para dentro de nossas casas. Graças à proliferação de canais e à portabilidade de novas tecnologias de informática e telecomunicações, estamos entrando numa era em que haverá mídias em todos os lugares (JENKINS, 2009, p. 42).

Seguindo o raciocínio de Jenkins, pode-se afirmar que a convergência não é algo que está por acontecer. "Prontos ou não" - afirma - "já estamos vivendo numa cultura de convergência" (Ibid., p. 42). Esse processo, certamente, tem consequências sobre as técnicas de comunicação mercadológicas no cenário da cultura de mídia, tema a ser tratado no tópico a seguir.

\title{
Técnicas de comunicação mercadológica aplicadas ao cenário de cultura de mídia: indícios de um desgaste do âmbito midiático
}

Uma vez apresentado o cenário dos estudos das mídias, torna-se necessário analisar as técnicas aplicadas pela publicidade para fazer uso desta multiplicidade de meios de comunicação para a finalidade comercial que ela se propõe. Para isso, recorro às ideias de James R. Ogden e Edson Crescitelli (2007), desenvolvidas no livro Comunicação Integrada de Marketing: Conceitos, Técnicas e Práticas. Na introdução dessa publicação, os autores colocam em destaque os desafios que cercam a ideia de planejamento de comunicação em um cenário de grande competitividade.

\begin{abstract}
Montar um plano de comunicação integrada de Marketing é como planejar sua viagem pelo país. O plano de CIM é seu mapa rodoviário de comunicação - ajuda a criar um plano de ação concreto. Você define um ponto de partida e um destino. Como você chega ao destino, partindo de onde está? Quais são os seus prazos? Qual é seu orçamento? (OGDEN; CRESCITELLI, 2007, p. xi).
\end{abstract}

A analogia de um planejamento de viagem cumpre a função de apresentação didática do âmbito comunicacional pelo ponto de vista comercial. $\mathrm{O}$ uso desse exemplo torna clara a situação de constante mudança e aumento de competitividade no cenário mercadológico atual, também colocado em perspectiva histórica pelos autores:

Para tornar seu planejamento ainda mais complexo, imagine que, além de todas essas variáveis, o ambiente que você uti- 
lizará para viajar está em constante mutação. Novas tecnologias fazem surgir novas formas de comunicação. É como se surgissem, a todo tempo, novas estradas, novas opções. Além disso, considere ainda que muitas da estradas que você pretende utilizar - em geral as mais seguras e mais conhecidas - estão cada vez mais congestionadas, pois, assim como você, todas as outras empresas também querem atrair a atenção do mercado para seus produtos e serviços. Fazer comunicação de marketing atualmente é um processo muito mais complexo do que em tempos passados, quando o mercado tinha baixo nível de segmentação (...) e as mídias eram poucas e com grande poder de penetração. O rádio tinha a hegemonia da audiência nas décadas de 1940 e 1950, depois foi a vez da televisão nas décadas seguintes, de 1960 e 1970 . Tudo muito diferente dos dias atuais (OGDEN; CRESCITELLI, 2007, p. xi).

A base da teoria e aplicação do que os autores chamam de comunicação integrada de marketing é que, no cenário de múltiplas possibilidades de veiculação de mensagens publicitárias, os profissionais desta área devem utilizar-se dos meios de comunicação de forma integrada e coesa. O que deve ser colocado em foco aqui é a priorização da mensagem publicitária em detrimento de uma vasta gama de opções de meios de comunicação.

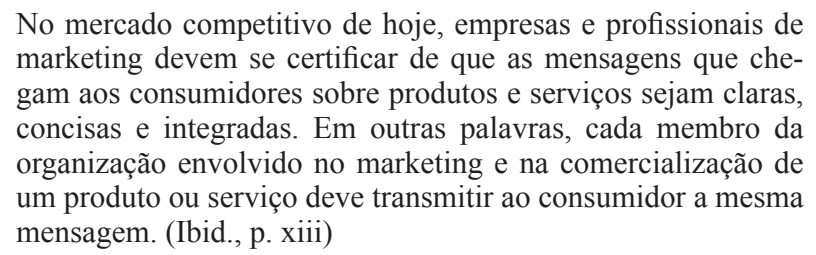

Quando estes autores colocam que a base para a eficácia da comunicação integrada de marketing é a repetição da mesma mensagem publicitária em qualquer meio de comunicação a ser utilizado, isto se transforma em prática indiscutível pelos profissionais de planejamento. É quase como uma volta à análise de McLuhan (2003) sobre o meio ser a mensagem. Ou seja, o meio de comunicação tem seu valor no planejamento de comunicação empresarial somente quando lhe é atribuída uma mensagem, ou seja, um conteúdo. E este conteúdo deve ser repetido em todas as facetas do âmbito midiático para convencer, e não confundir, o consumidor sobre as funções e benefícios de determinado produto e serviço.

O que Ogden e Crescitelli (2007), assim como outros publicitários e até anunciantes, não preveem, ou parecem não assimilar por completo, é exatamente a noção de cultura de convergência. As teorias anteriores ao cenário apresentado por Jenkins tratam de forma linear a multiplicação de mensagens 
no âmbito midiático. Justamente o oposto do que estes autores afirmam. A falta de conhecimento sobre esse novo cenário comunicacional, cujos resultados são impactantes na geração de conteúdo por todos os agentes participantes, fica evidente numa avaliação de Jenkins, feita num painel de discussão de uma Conferência Internacional sobre convergência sediada em New Orleans no ano de 2003:

Em um painel sobre consoles, a grande tensão foi entre a Sony (uma empresa de hardware) e a Microsoft (uma empresa de software); ambas tinham planos ambiciosos, mas visões e modelos de negócios fundamentalmente distintos. Todos concordaram que o principal desafio era expandir os usos potenciais dessa tecnologia barata e prontamente acessível, para que se tornasse a 'caixa preta', o 'cavalo de Tróia', que clandestinamente levaria a convergência às salas de estar das pessoas. O que mamãe faria com o console enquanto os filhos estivessem na escola? $\mathrm{O}$ que levaria uma a dar um console de videogame para o vovô no Natal? Eles tinham a tecnologia para efetuar a convergência, mas não sabiam por que alguém iria querer usá-la (JENKINS, 2009, p 33).

Este depoimento revela que mesmo empresas de grande porte, como Sony e Microsoft, ainda não estavam tão seguras sobre como se portar diante deste novo cenário de comunicação midiática. $\mathrm{O}$ que não é de se espantar, uma vez que os conhecimentos prévios que tais empresas dispunham sobre convergência ainda não contemplavam tais complexidades.

Como a Cheskin Research explicou num relatório de 2002, 'a velha ideia de convergência era de que todos os aparelhos iriam convergir num único aparelho central que faria tudo para você (à la controle universal). O que estamos vendo hoje é o hardware divergindo, enquanto o conteúdo converge [...] (JENKINS, 2009, p. 42).

A multiplicação de conteúdos dentro da cultura de mídia, apontada por Kellner em 2001, em um cenário de cultura de convergência, que Jenkins delimitaria em 2009, continua acontecendo e se intensificando hoje, assim como ele previra:

Empresas de mídia estão aprendendo a acelerar o fluxo de conteúdo de mídia pelos canais de distribuição para aumentar as oportunidades de lucros, ampliar mercados e consolidar compromissos com o público. Consumidores estão aprendendo a utilizar as diferentes tecnologias para ter um controle mais completo sobre o fluxo e mídia e para interagir com outros consumidores. As promessas desse novo ambiente de mídia 
provocam expectativas de um fluxo mais livre de ideias e conteúdos. Inspirados por esses ideais, os consumidores estão lutando pelo direito de participar mais plenamente de sua cultura. (JENKINS, 2009, p. 46).

Como mencionado no início deste artigo, um dos objetivos da contextualização teórica realizada até aqui é apontar o impacto desta aceleração do fluxo de conteúdos de mídia no âmbito comunicacional. Num cenário de convergência, a multiplicação não-linear de conteúdos produzidos pela cultura de mídia começa a apresentar consequências. Quer parecer que a principal delas é a de um certo desgaste do âmbito midiático, cuja expressão começa a se manifestar em certos segmentos de consumidores.

A título de exemplo, no dia 25 de abril de 2014, Gary Turk, um jovem britânico produziu e publicou na Internet um curta metragem intitulado Look Up - ou Olhe Para Cima - que ele mesmo chamou de um filme "falado para uma geração online". O conteúdo da produção é um manifesto para que as pessoas deixem de enxergar o mundo através da tela do celular. O título do filme se refere exatamente à ideia de parar de olhar para baixo, para a tela, e olhar para cima, para o real.

Tenho 422 amigos, mas sou solitário.

Falo com eles todos os dias, mas nenhum deles realmente me conhece. [...]

Dei um passo para trás e abri meus olhos

Olhei em volta e percebi

Que esta mídia que chamamos de social não é nada disso

Quando abrimos nossos computadores, são nossas portas que fechamos.

Toda essa tecnologia que temos, é só uma ilusão

De comunidade, companheirismo, um senso de inclusão

Quando você se distancia deste aparelho de delírio,

Você acorda para ver um mundo de confusão [...]

Um mundo de auto interesse, auto imagem e auto promoção

Em que compartilhamos nosso melhor, mas deixamos fora a emoção $[\ldots]$

Então quando estiver em público, e começar a sentir sozinho, Coloque as mãos atrás da cabeça, saia do telefone [...]

Estamos cercados de crianças, que desde que nasceram

Nos veem vivendo como robôs, e acham normal.

Não é muito provável que você será o melhor pai do mundo

Se não conseguir entreter uma criança sem o uso de um iPad [...]

Sou culpado também, de ser parte desta máquina

Deste mundo digital, em que somos ouvidos mas não vistos.

Que passamos horas juntos, sem fazer contato visual [...]

Não se entregue a uma vida de modismo

Dê seu amor para as pessoas, não o seu curtir [...]

Olhe para cima, feche o display

Pare de ver este vídeo, viva a vida do jeito real. (TURK, 2014) 
O vídeo de Gary Turk foi visualizado, somente em seu canal oficial, mais de 50 milhões de vezes e foi traduzido em diversas línguas em incontáveis compartilhamentos no ano de 2014. O que esse exemplo traz à tona é que a intenção de favorecer este comportamento de "vá para a rua" demonstra uma vontade, ou uma demanda latente dos indivíduos, por uma certa "libertação" destes conteúdos e normas comportamentais entregues ou intensificados pela cultura de mídia. Estamos observando agora um favorecimento da geração de conteúdos e experiências reais efetivamente vividas pelas pessoas.

Esse tipo de comportamento, quase de contracultura, mereceu atenção de Henry Jenkins, ao referir-se, na obra analisada neste trabalho, ao projeto Setas Amarelas.

\begin{abstract}
Pessoas no mundo todo estão afixando adesivos de Setas Amarelas (http://global.yellowarrow.net) nas laterais de monumentos e fábricas, sob viadutos e em postes. As setas fornecem números para os quais outras pessoas podem ligar e acessar mensagens de voz gravadas - comentários pessoais sobre a paisagem urbana. Usam essa gravação para partilhar uma linda paisagem ou criticar empresas irresponsáveis. E, cada vez mais, empresas estão cooptando o sistema para deixar sua própria publicidade (JENKINS, 2009, p. 46).
\end{abstract}

O projeto Setas Amarelas (Yellow Arrows) foi um projeto público de arte, criado por Michael Counts, Cristopher Allen, Brian House e Jesse Shapins, que esteve ativo entre 2004 e 2006. Os adesivos de setas amarelas eram distribuídos pelo site do projeto e colocados em qualquer lugar do espaço público. Ao encontrar um adesivo na rua, o pedestre poderia enviar o código impresso no adesivo para o telefone do projeto (via SMS) e receberia de volta uma história contada pela pessoa que o divulgou.

Este é um exemplo do processo de multiplicação não-linear de conteúdo a que se refere Jenkins, mas também explicita outro fato. $O$ sucesso do projeto, aplicado em mais de 460 cidades, em 35 países, foi creditado, pelos seus autores, à vontade dos participantes de escutarem histórias reais enquanto visitavam os locais fisicamente. A utilização do espaço público urbano para o funcionamento desse projeto foi de suma importância.

Essa nova abordagem temática, de experiências reais vividas pelos sujeitos se assemelha a uma não-publicidade ou a uma antipublicidade, porém já foi incorporada a estratégias de comunicação comercial. Anunciantes se colocam na posição de pedir sensações "mais reais" dos consumidores para que uma percepção de identificação seja produzida. É como se o anunciante, paradoxalmente, pedisse ao consumidor que ele se solte das "verdades" da 
cultura de mídia, que ele "reaja", na linha proposta por Kellner (2001), quando afirma que há espaço para questionamento dos valores culturais veiculados pelos meios de comunicação.

A busca por um discurso de relativa liberdade fica evidente também na campanha da marca de vodca Smirnoff, desenvolvida pela Diageo, em julho/ agosto de 2014, em algumas capitais do Brasil. Com foco no público jovem, a campanha pretendia - por meio de cartazes vermelhos com frases em branco espalhadas em pontos estratégicos de grandes cidades como São Paulo, Rio de Janeiro, Belo Horizonte, Goiânia e Brasília - gerar uma um processo de identificação com target em conteúdos de contestação de algumas normas de comportamento presentes em suas vidas cotidianas. Vidas estas - é bom lembrar - que não deixam de ser influenciadas culturalmente pela mídia. A figura abaixo é ilustrativa desse exemplo.

Figura 1 - Smirnoff é a marca por trás da campanha 'Um brinde à vida real'

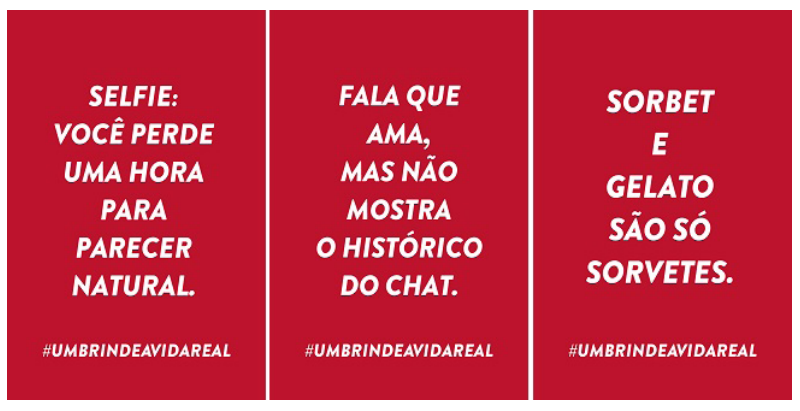

Fonte: LOPES, 2014.

Frases como "Selfie: você perde uma hora para parecer natural" ou "Sorbet e Gelato são só sorvetes" são pensadas e veiculadas com o intuito de questionar o comportamento dos jovens. Colocar em xeque valores como a autopromoção, por meio do riso, da autoavaliação e dos autorretratos (ou selfies, moda contemporânea possibilitada pela câmera frontal da maioria dos smartphones atuais; ou, ainda, de processos com a nomenclatura gourmet em alimentos triviais e comuns) tem o objetivo de buscar uma identificação com conteúdos que reforçam a busca por experiências mais reais e menos "fabricadas" pela cultura de mídia.

\section{O uso do espaço público sob a ótica publicitária}

No dia 4 de setembro de 2014, a marca de cerveja Sol (marca pertencente à Heineken Brasil) veiculou uma campanha publicitária intitulada de Espirutu 
Libre (Espírito Livre). A campanha, desenvolvida pela agência Talent, é baseada no conceito de "uma declaração de independência para aqueles que resistem à pressão do conformismo, e afirmam a sua liberdade fazendo as coisas do seu jeito", conforme publicado em matéria especial no portal da revista Exame (2014).

A campanha utilizou-se de alguns vídeos que contam histórias de pessoas que tomaram rumos não convencionais em suas vidas pessoais e profissionais e, por tais decisões, são apontadas como únicas na investida de comunicação da marca. O que chama atenção para esta campanha não é o uso de um discurso de "libertação" ou de simples "reação" à cultura de mídia. O ponto de suporte da estratégia de comunicação da marca é a sustentação de que pessoas com "espírito livre" se apropriam do espaço das cidades em que moram para reafirmarem essa proposta libertação.

O incentivo à exploração de espaços urbanos vai ao encontro do que foi indicado anteriormente como uma "vontade" ou "demanda latente" de "libertação", por parte dos consumidores, em função de um desgaste causado pelo excesso de informações (que aqui se apresentam como descartáveis) veiculadas pelos meios de comunicação. A campanha da cerveja Sol sugere uma postura de "pedido", direcionado ao público que se identifica com esta "causa", para que efetivamente criem suas próprias experiências, em contato com os espaços da cidade. Isso fica evidente não só nos materiais promocionais veiculados pela campanha (figuras 2 e 3), mas também em iniciativas de suporte a este pleito.

Figura 2 - Nada como sair do trabalho e dar de cara com o sol.

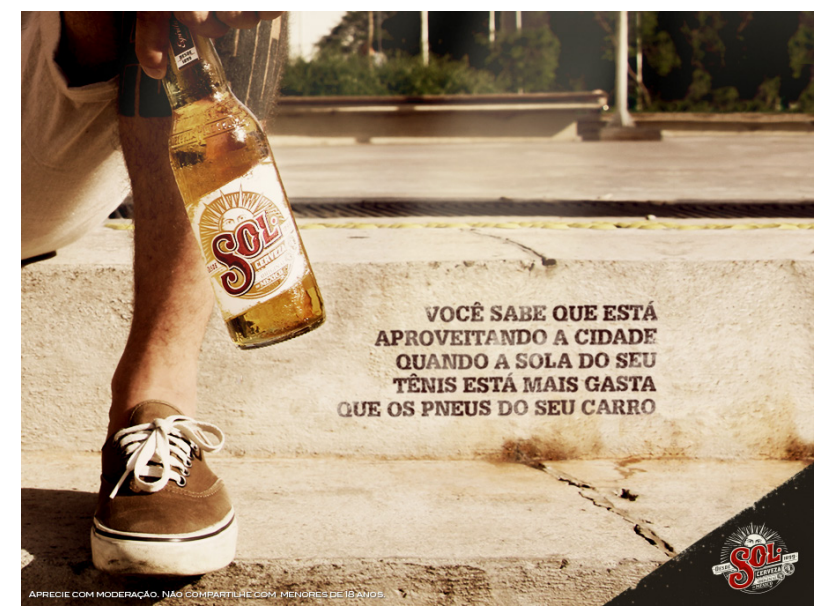

Fonte: Sol Beer/Facebook, 2015

Por iniciativas de suporte a este pleito, refiro-me à publicação de um website, desenvolvido pela campanha da marca, intitulado de SolSearch, ilustrado na figura 3 . 
Figura 3 - Se você busca lugares autênticos, procure em: www.solsearch.com.

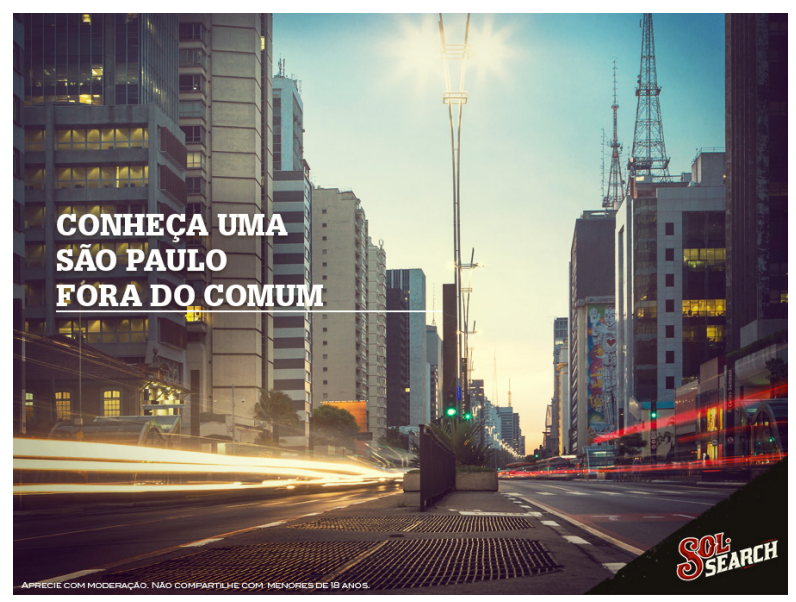

Fonte: Sol Beer/Facebook, 2015

Trata-se de um ambiente virtual no qual o consumidor é convidado a colocar sua idade e sua localização na cidade em dado momento para que lhe seja fornecido uma lista de locais, fora do circuito convencional da cidade, nos quais poderá ser experimentada uma "nova" sensação de convívio urbano.

\section{Considerações finais}

A partir de uma breve retrospectiva histórica das teorias que abordam a mídia e os meios de comunicação, procurou-se demarcar a evolução de algumas análises conceituais acerca do comportamento social e seu impacto em outro fenômeno social: a propaganda. Vimos que McLuhan (2003), em sua contemporaneidade, apresentou os veículos de comunicação, fazendo uma distinção entre eles, a partir de conceitos de participação dos usuários e da interpretação das informações veiculadas com o objetivo de fundamentar sua posição de que a mídia como "extensões do homem" abre espaço para a disseminação e consolidação de certas visões políticas e ideológicas.

Kellner (2001), por sua vez, argumenta que, por uma onipresença do campo midiático nas vidas cotidianas, valores e posições culturais são veiculados pelos meios de comunicação e que tais valores definem posições e determinações no âmbito social. Isto é, contribuem para a delimitação de uma linha divisória entre comportamentos e visões socialmente aceitáveis ou não. O que Kellner traz, em contraste com a teoria de McLuhan, é a capacidade do indivíduo de aceitar ou negar estes valores culturais. Vimos que a teoria de Kellner, 
até pelo momento em que foi publicada, não contempla a Internet como um dos meios de comunicação desse cenário.

Por fim, Jenkins (2009) apresenta o ambiente virtual como pano de fundo de sua teoria, segundo a qual a rede mundial de computadores é o espaço onde acontece o que ele chama de "transformação cultural", e não só tecnológica: a cultura de convergência. Jenkins aponta que o conteúdo transita, na atualidade, de forma não-linear e, assim, realoca a posição tradicional de comunicação, fazendo de todos os participantes, emissores e receptores de mensagens, agentes de mudança.

Por meio dessa análise conceitual, e com base em alguns exemplos, procurou-se argumentar que a aceleração do fluxo de informações por agentes de mídia resulta em um "desgaste" da cultura midiática, caracterizada pelo "excesso de informações" a que os indivíduos estão expostos atualmente. Esse "desgaste", e as consequentes reações aversivas aos excessos produzidos pela cultura de mídia, parecem indicar uma demanda social (e dos consumidores) por novos espaços, por experiências mais "reais". Este fenômeno pode explicar a popularidade de manifestos antimidiáticos e antitecnológicos da vida cotidiana, como o divulgado no vídeo de Gary Turk. Sugere-se, então, que a fuga do ambiente midiático pode ser expressão da vontade dos indivíduos de se apropriarem do espaço urbano, exatamente porque este parece adquirir um novo significado: o da reconquista de uma certa "libertação" do âmbito midiático e virtual. Dessa forma, a "rua" acaba assumindo o papel de "mundo real".

Diante disso, procurou-se argumentar também que esse desgaste do ambiente midiático e das "normas comportamentais" por ele veiculadas, vem sendo, de certa forma, identificada por empresas anunciantes, o que se revela nas temáticas de campanhas publicitárias que investem na ideia de "reconquista" de experiências "reais", vividas, principalmente, no espaço público urbano. Uma rápida leitura dos comentários de consumidores postados na página da campanha da marca Sol, em redes sociais, permite perceber que, a investida da empresa na comunicação publicitária em locais "não convencionais", ou "autênticos", não só agrada o consumidor, mas acaba sendo apropriada por ele como uma nova postura, como uma experiência real, vivida como um componente individual de expressão cultural:

Adoro esta cidade e seus lugares a serem descobertos Até que enfim uma marca que não apela para o sensacional apela mais para o real (comentários de consumidores postados na página SOL Beer/Facebook, 2015). 
Com o raciocínio construído até aqui não se pretende dizer que o consumidor vai se desconectar da cultura da mídia, ou dos aspectos de convergência enfatizados por Kellner (2001) e Jenkins (2009), mas sim que os indivíduos começam a utilizar-se dos ambientes midiáticos como ferramentas de geração e multiplicação de conteúdos com os quais se identificam pessoalmente, e também de compartilhamento de experiências "reais", vividas nos espaços públicos, urbanos. E que essa tendência tem sido percebida e utilizada pelos anunciantes para o desenvolvimento de campanhas que visam aumentar a audiência de seus esforços promocionais.

O estudo e a reflexão sobre estes temas são de suma importância, pois, como James R. Ogden e Edson Crescitelli (2007, p.XI) apontam - retomando o exemplo do mapa rodoviário sob a ótica de planejamento de comunicação - "muitas das estradas que você pretende utilizar - em geral as mais seguras e mais conhecidas - estão cada vez mais congestionadas."

\section{Referências}

EXAME.com. Espíritu Libre" explica a cerveja Sol Premium em novo filme. Exame.com. Marketing - 04/09/2014. Disponível em: <http://exame.abril.com.br/marketing/noticias/espiritu-libre-explica-a-cerveja-sol-premium-em-novo-filme> Acesso em: 15 jan. 2015.

JENKINS, Henry. Cultura da Convergência. 2a. ed. São Paulo: Aleph, 2009. 428 p.

KELLNER, Douglas. A Cultura da mídia. Estudos culturais: identidade e política entre o moderno e o pós-moderno. Bauru, SP: EDUSC, 2001. 452 p.

KYNASTON, David. Modernity Britain: Opening the Box, 1957- 1962. New York, Bloomsbury USA, 2014. $872 \mathrm{p}$.

LOPES, Yuri. Smirnoff é a marca por trás da campanha 'Um brinde à vida real' - AR - A Redação. Goiânia, 24.08.2014 Disponível em: <http://www.aredacao.com.br/negocios/47466/ smirnoff-e-a-marca-por-tras-da-campanha-um-brinde-a-vida-real\#sthash.AQ9GwARe.dpuf > Acesso em: 07 jan. 2015.

OGDEN, James R.; CRESCITELLI, Edson. Comunicação Integrada de Marketing. Conceitos, técnicas e práticas. 2a. ed. São Paulo: Pearson Prentice Hall, 2007.

McLUHAN, Marshall. Os meios de comunicação como extensões do homem. 13a. ed. São Paulo: Editora Cultrix, 2003.

RUBIN, Martin. Before the Beatle's First LP. New TVs, refrigerators, washing machines-no wonder Britain's prime minister said the nation had never had it so good. The Wall Street Journal, Life \& Culture, Jan. 2, 2015. Disponível em: <http://www.wsj.com/articles/book-review-modernity-britain-1957-1962-by-david-kynaston-1420229395> Acesso em: 05 jan. 2015 . 
SOL Beer/Facebook. Nada como sair do trabalho e dar de cara com o sol. Disponível em:< https://www.facebook.com/solbeer?ref=ts\&fref=ts> Acesso em: 05 jan. 2015.

. Se você busca lugares autênticos, procure em... Disponível em: $<$ https://www.facebook.com/solbeer?ref=ts\&fref=ts $>$ Acesso em: 05 jan. 2015.

TURK, Gary. Look Up. A spoken word film for an online generation. Publicado em 25 abr. 2014. Disponível em: <https://www.youtube.com/watch?v=Z7dLU6fk9QY> Acesso em 15 jan. 2015.

Submissão em: 25/02/2015

Revisão em: 14/07/2015

Aceite em: 16/08/2015

Enrico Rosa Trevisan é bacharel em Comunicação Social pela Escola Superior de Propaganda e Marketing (ESPM), Mestre em Educação, Arte e História da Cultura pela Universidade Presbiteriana Mackenzie (2011), professor do Centro Universitário Senac, São Paulo/SP nos cursos de Publicidade e Propaganda, Marketing e Administração de Empresas. Endereço para correspondência: Avenida Engenheiro Eusébio Stevaux, 823. Santo Amaro, São Paulo/SP, Brasil. CEP 04696-000 E-mail: enricotrev@yahoo.com.br 